\title{
Erratum to: Prevalence of tetracycline resistance genes among multi-drug resistant bacteria from selected water distribution systems in southwestern Nigeria
}

\author{
Ayodele T. Adesoji ${ }^{*}$, Adeniyi A. Ogunjobi², Isaac O. Olatoye ${ }^{3,4}$ and Douglas R. Call ${ }^{4,5}$
}

\section{Erratum to: Annals of Clinical Microbiology and Antimicrobials (2015) 14:35 \\ DOI 10.1186/s12941-015-0093-1}

After publication of the original article the authors realised that Douglas. R. Call's name was displayed incorrectly. The correct spelling of his name is included in this erratum; the correct spelling has also been updated in the original article. The authors realised that in Line 347-"AAT" should have been "ATA", and "OAA" should have been "AAO". In Line 348-"OIO" should have been "IOO", "CRD" should have been "DRC" and "AAT" should have been "ATA". In Line 349-"OIO" should have been "IOO" and "CRD" should have been "DRC". In Line 325" 47 " should have been " 41 ". In Line $329-" 48$ " should have been " 47 ". In Line 340- "49" should have been " 48 ". In Line 503 reference ' 47 ' should be removed. In Line 506- ' 48 ' should have been ' 47 ' and in Line 510 -reference ' 49 ' should have been ' 48 '.

\section{Author details}

${ }^{1}$ Department of Biological Sciences, Federal University Dutsin-Ma, Dutsin-Ma, Katsina State, Nigeria. ${ }^{2}$ Department of Microbiology, University of Ibadan, Ibadan, Oyo State, Nigeria. ${ }^{3}$ Department of Veterinary Public Health and Preventive Medicine, University of Ibadan, Ibadan, Oyo State, Nigeria. ${ }^{4}$ Paul G. Allen School for Global Animal Health, Washington State University, Pullman, WA, USA. ${ }^{5}$ Department of Veterinary Microbiology and Pathology, Washington State University, Pullman, USA.

The online version of the original article can be found under doi:10.1186/s12941-015-0093-1.

Published online: 11 September 2015

\footnotetext{
${ }^{*}$ Correspondence: timmyayus2002@yahoo.com

1 Department of Biological Sciences, Federal University Dutsin-Ma,

Dutsin-Ma, Katsina State, Nigeria

Full list of author information is available at the end of the article
} 